\title{
Vegetal recovery following wildfire in seeded and unseeded sagebrush steppe
}

\author{
TERESA D. RATZLAFF AND JAY E. ANDERSON
}

Authors are Senior Research Assistant and Professor, Department of Biological Sciences, Box 8007, Idaho State University, Pocatello 83209-8007.

\begin{abstract}
Following an August wildfire, sagebrush (Artemisia L.)/grass benchlands adjacent to Pocatello, Ida., were seeded with a mixture of exotic wheatgrasses and forbs by rangeland drill in November 1987. The effects of seeding on vegetation development in the immediate postfire years were evaluated by comparing plant density, vegetal cover, species composition, species diversity, and standing crop in seeded areas to that in unseeded control plots in 1988 and 1989. We also examined cover of bare ground, litter, and growth form between treatments and between sampling periods. Twenty paired $10-\mathrm{m}$ transects were established in seeded and unseeded areas on each of 3 plots on the burned benches. Plant density, vegetal cover, and species diversity were lowrer in the seeded areas than in the unseeded areas in 1988 and 1989. Species composition, species richness, and standing crop were similar between treatments. Establishment of seeded species was poor, probably as a result of drought conditions in 1987 and 1985. Most plants observed in seeded and unseeded areas in the spring of 1988 sprouted from established perennials. Even though the first postfire season was a drought year, plant cover in the unseeded areas (18.3\%) approached that estimated by a U.S. interagency task force as needed to stabilize soils on that site. In the following year, which had average precipitation, plant cover in both treatments exceeded the task force's estimate of prefire cover. Because the indigenous plant species recovered rapidly, seeding of this burn was unnecessary to establish plant cover and counterproductive in terms of erosion potential. These results serve to emphasize that objective criteria should be established for evaluating the necessity of postfire seeding.
\end{abstract}

Key Words: rehabilitation, rangeland drill, exotic species, fireadapted species, Bromus tectorum, Artemisia

Eecause of an evolutionary history that included periodic wildfires, many of the native species in the Intermountain West of North America are well adapted to cope with recurring fire. Nonetheless, land managers often recommend seeding of burned rangelands to augment vegetation recovery and reduce erosion without considering the resilience of the prefire vegetation or the potential negative impacts of seeding. Species used for rehabilita-

Research was funded in part by the U.S. Bureau of Land Management, Pocaiello, Ida.

Minuscript accepted 27 Dec. 1994. tion of bumed rangelands are usually exotics, favored because of their availability and adaptation to a broad range of environments and heavy grazing pressure (Hull and Klomp 1966, Wright and Bailey 1982, Rogler and Lorenz 1983). However, many of these introduced species are highly competitive and may displace native species (Hull 1971). Crested wheatgrass (Agropyron cristatum [L.] Gaertn. and related taxa), a widely seeded species, tends to form persistent dominant stands (Schuman et al. 1982) that are resistant to invasion (Marlette and Anderson 1986).

In August of 1987, a wildfire burned some 1,085 ha of sagebrush (Artemisia)/grass/juniper (Juniperus) benchlands near Pocatello, Ida. An emergency management plan (CCEFRP 1987) recommended rehabilitation by seeding. The stated objectives of the plan were to 1) achieve at least $30 \%$ vegetative cover by September 1988, 2) reduce soil losses, 3) limit cheatgrass invasion to $10 \%$ composition within 3 years, and 4 ) improve wildlife habitat. The plan's authors estimated that vegetative cover before the fire was about $30 \%$, and without seeding, only $10-15 \%$ could be expected the first year. They projected that growth form composition by weight in seeded areas would be $75 \%$ grasses, $15 \%$ forbs, and $10 \%$ shrubs after 4 years. Additionally, the authors estimated that at least $20 \%$ vegetative ground cover would be necessary to minimize erosion.

In November of 1987, about 128 ha of these benchlands were seeded with a rangeland drill. Three plots within the seeded area were left unseeded and undisturbed by drilling. We initiated a study on this site in the spring of 1988 to address the effects of the seeding in relation to the short-term objectives of the emergency management plan. To that end, we compared vegetation development in areas seeded by drilling to that of unseeded controls during the 2 growing seasons following the fire.

\section{Methods}

\section{Study Area}

This study was conducted on burned benchlands immediately southwest of Pocatello, Ida., at elevations ranging from 1,500 to $1,600 \mathrm{~m}$. The soils are coarse-silty, mixed, frigid Calcic Haploxerolls of the Ririe series. We have no prefire vegetation data for this area, but casual observation of adjacent vegetation and cover data from the postfire study plots document that before the fire the study area supported a diverse community of native shrubs and forbs and native and naturalized perennial grasses 
(Table 1). The unbumed vegetation of immediately adjacent areas is dominated by three-tip sagebrush (Artemisia tripartita Rydb.), but basin big sagebrush (A. tridentata Nutt subsp. tridentata) and mountain big sagebrush (A. tridentata Nutt subsp. vaseyana) are also present. Antelope bitterbrush (Purshia tridentata [Pursh] DC.), rabbitbrush (Chrysothamnus viscidiflorus [Hook.] Nutt. and $C$. nauseosus [Pall.] Britt.) and Utah juniper (J. osteosperma [Torr.] Little) occur as scattered individuals. The study site faces northeast and lies on a broad bench between City Creek and Cusick Creek. At the time of the fire, the City Creek area had not been grazed by livestock since about 1950 (R. Swanson, person. comm.).

Average annual precipitation at Pocatello is $276 \mathrm{~mm}$, with the greatest percentage falling as snow during the winter months and as rain in spring (Fig. 1). Summers are typically warm and dry and potential evapotranspiration far exceeds precipitation. During the period from 1 October. 1987, through 30 September 1988, the area received only $162 \mathrm{~m}$ of precipitation. This exceptionally dry year was followed by $281 \mathrm{~m}$ precipitation during the same period in 1988/89 (Fig. 1).

Table 1. Common plant species in City Creek area, Pocatello, Ida, and percent cover in unseeded plots, July 1989. Species without cover values listed did not occur in the unseeded study plots, but were present in the surrounding area.

\begin{tabular}{|c|c|c|}
\hline & Common Name & $\begin{array}{c}\% \\
\text { Cover }\end{array}$ \\
\hline \multicolumn{3}{|l|}{ Grosses } \\
\hline $\begin{array}{l}\text { Elymus lanceolatus } \\
\text { (Scribner \& J.G. Smith) Gould }\end{array}$ & thickspike wheatgrass & 1.75 \\
\hline $\begin{array}{l}\text { Pseudoroegneria spicata } \\
\text { (Pursh) A. Love subsp. spicata }\end{array}$ & bluebunch wheatgrass & 0.54 \\
\hline Pos bulbosa L & bulbous bluegrass & 6.69 \\
\hline Foa nevadensis Vasey & Nevada bluegrass & 0.15 \\
\hline Poa sanabergii Vasey & Sandberg's bluegrass & 0.25 \\
\hline Elymus elymoides (Rafin.) Swezey & squirreltail & 0.31 \\
\hline Stipa comata Trin. \& Rupr. & needle-and-thread & 1.99 \\
\hline \multicolumn{3}{|l|}{ Foriss } \\
\hline Astragalus convallarins Greene & lesser rushy mildvctch & 1.00 \\
\hline Crepis acuminata Nutt. & tapertip hawksbeard & 9.84 \\
\hline Comandra umbellata (L.) Nutt. & bastard toad-flax & 0.61 \\
\hline Erigeron L. spp. & fleabane & 1.14 \\
\hline Laciuca scrriola L. & prickly lettuce & 0.33 \\
\hline Lithospermum ruderale Dougl. & Columbia puccoon & 1.01 \\
\hline Lapinus L. spp. & lupine & 1.16 \\
\hline Penstemon Mitch. spp. & penstemon & 0.83 \\
\hline Fhlox hoodii Rich. & Hood's phlox & 1.11 \\
\hline Phlox longifolia Nutt. & long-leaf phlox & 1.10 \\
\hline \multicolumn{3}{|l|}{ Shrouks } \\
\hline Accr grandidentatum Nutt. & bigtooth maple & \\
\hline Aremisia triparita Ryób. & cut-leaf sagebrush & 0.06 \\
\hline Aremisia tridentata Nutt. spp. & big sagebrush & \\
\hline Chrysothammas nauseosus (Pall.) Britt. & gray rabbitbrush & 0.45 \\
\hline $\begin{array}{l}\text { Chrssothanmits viscidifforus } \\
\text { (Hook.) Nuts. }\end{array}$ & green rabbitbrush & 1.44 \\
\hline Junipents osteosperma (Torr) Little & Utah juniper & \\
\hline Juniperus scopuloram Sarg. & Rocky Mountain juniper & \\
\hline Purshia tridentata (Pursh) DC. & antelope bitterbrush & 0.14 \\
\hline Rosa woodsii Lindl. & Wond's rose & 0.11 \\
\hline Symphoricarpos albuss (L.) Blake & common snowberry & 0.16 \\
\hline Tetradymia canescens $D C$. & horsebrush & \\
\hline
\end{tabular}

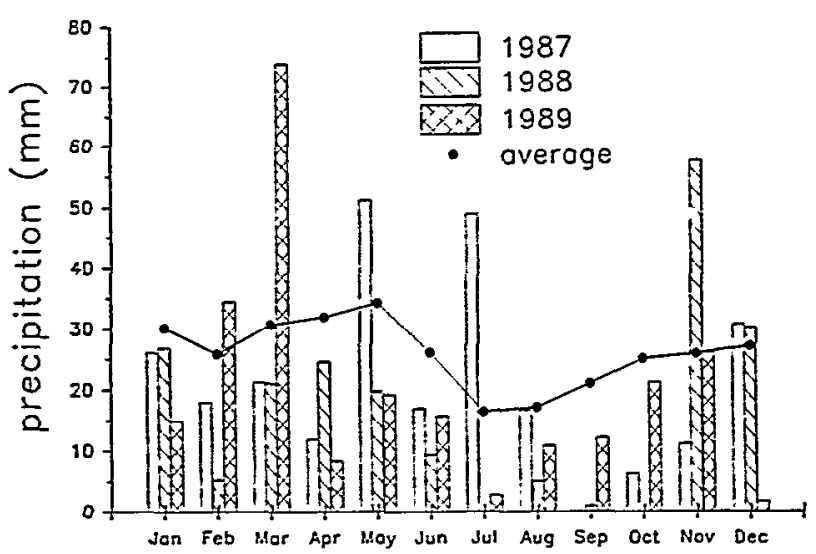

Fig. 1. Total monthly precipitation for 3 years and average monthly precipitation for 90 years of record for Pocatello, Ida. (National Oceanic and Atmospheric Administration, 1989).

\section{Seeding and Plot Arrangement}

The area was seeded in November of 1987 using a rangeland drill equipped with regular furrow openers. There was no preparative tillage. A mixture of 3 exotic wheatgrasses, a cultivar of a native wheatgrass, and 2 exotic forbs (Table 2) was drilled at a rate of $13 \mathrm{~kg} \mathrm{ha}^{-1}$ (CCEFRP 1987). Before seeding, Idaho State University plant ecologists and U.S. Bureau of Land Management personnel selected 3 plots within the burn as control areas to be left unseeded and undisturbed. The plots were chosen as representative of the area to be seeded based on aspect, elevation, burn intensity, and apparent similarity of prefire vegetation. These 3-ha plots were each about $60 \mathrm{~m}$ wide and extended on the contour across the width of the bench (about $0.5 \mathrm{~km}$ ). The elevation of the lower plot was about $1,500 \mathrm{~m}$, that of the middle plot $1,600 \mathrm{~m}$, and the upper plot was about $1,650 \mathrm{~m}$.

A $100-\mathrm{m}$ baseline starting near the edge of the bench adjacent to Cusick Creek was established at the interface of the seeded and unseeded areas on the lower and upper plots. A $200-\mathrm{m}$ baseline was established similarly on the middle plot. Twenty random points corresponding to meter intervals were chosen on each baseline. For each baseline point, a distance perpendicular to the baseline was randomly chosen and a pair of $10-\mathrm{m}$ transects was established at equal distances from the baseline in the unseeded and seeded areas. The transects were oriented parallel to the slope.

\section{Sampling}

The proportion of soil disturbed by the drilling process was estimated by line interception from a photographic slide taken immediately following drilling. The slide was projected onto a screen and furrow width was measured with a ruler on 3 transects perpendicular to the furrows. Transects were chosen to represent the entire area viewed in the photograph. Disturbance caused by furrowing was calculated as a percentage of transect length.

Seedlings were counted in twenty $10-\mathrm{m}$ lengths of furrow, chosen randomly in the seeded areas in the upper and middle plots (400 m total). Seedlings were reported as grass or forb. Percent 
Table 2. Composition of drill mix used for seeding burned benches in the City Creek area, Pocatella, Ida., 1987, and estimated cover of drilled species on transects in July, 1989. A. riparium is a cultivar of Elymus lanceolatus (Scribner \& J.G. Smith) Gould, a native species; all others are exotic. Inert materials, weed and crop seed comprise the remaining $2 \%$.

\begin{tabular}{|c|c|c|c|}
\hline \multirow[b]{2}{*}{ Spacies, Common Name and Cultivar } & \multirow[b]{2}{*}{ Mix } & \multicolumn{2}{|c|}{ Fc Cover July 1989} \\
\hline & & Seeded & Unseeded \\
\hline & ( $\%$ by weight) & \multicolumn{2}{|c|}{$\ldots(C) \cdots$} \\
\hline $\begin{array}{l}\text { Thinopyrum intermedinm subsp. } \\
\text { intemmedium } \\
\text { (Host) Barkw. E. D.R. Dewey } \\
\text { intermediate wheatgrass (Greenar) }\end{array}$ & 58 & 0.89 & 0.00 \\
\hline $\begin{array}{l}\text { Agroprron sibiricum (Willd.) Beauv. } \\
\text { Sibarian wheatgrass (P-27) }\end{array}$ & 10 & 1.67 & 0.14 \\
\hline $\begin{array}{l}\text { T. intermedium subsp. barbulatum } \\
\text { (Schur) Barkw. \& D.R. Dewey } \\
\text { pubescent wheatgrass (Luna) }\end{array}$ & 7 & 0.00 & 0.00 \\
\hline $\begin{array}{l}\text { A. riparium Scribn. \& Smith } \\
\text { streambank whentgrass (Sodar) }\end{array}$ & 4 & 3.45 & 3.83 \\
\hline $\begin{array}{l}\text { Sangutisorba minor Scop. } \\
\text { small burnet (Dslar) }\end{array}$ & 16 & 0.20 & 0.00 \\
\hline $\begin{array}{l}\text { Meáicago sativa } \mathrm{L} \\
\text { alfalfa (Ranger) }\end{array}$ & 3 & 0.03 & 0.00 \\
\hline
\end{tabular}

emergence was estimated as the number of seedlings per number of seeds planted.

Density of vascular plants was estimated from 14 April to 20 May 1988. All transects on the middle and upper plots were sampled. A $0.2 \times 0.5-\mathrm{m}$ frame was placed directly on the soil surface at distances of 2 and $6 \mathrm{~m}$ on the north side of each transect, and the number of individual plants within the frame was recorded by species. A sample unit consisted of 2 frames, or $0.2 \mathrm{~m}^{2}$. Twenty samples per treatment were collected on each plot. Data from paired transecrs were collected on the same day.

Cover of vascular plants was estimated during 3 sampling periods; 8 June to 11 August 1988, 20 May to 27 June 1989, and 12 July to 27 July 1989 . Ten of the established 20 pairs of transects from each plot were chosen randomly for cover sampling by point interception. Data from paired transects were collected on the same day. The $0.5 \times 1-\mathrm{m}$ frame (Floyd and Anderson 1982) had 36 interception points; it was placed at $1-\mathrm{m}$ intervals along the north side of each transect, providing 360 points per sample unit. Each point was recorded as a plant species, bare ground, or litter (nonliving plant material). Percent cover was calculated as the number of points intercepting a particular entity, divided by the total number of points.

Standing crop was harvested between 12 and 27 July 1989, at peak production (when seed of perennial grasses started to ripen), in seaded and unseeded areas on all plots. Ten of the established transects were chosen randomly at each plot in seeded and unseeded areas. A $1-\mathrm{m}^{2}$ plot was located $2 \mathrm{~m}$ from each transect used, between distance 4 and $5 \mathrm{~m}$, and parallel to the transect. All plants within each plot were harvested at the soil surface and sorted by species. Samples were dried at $80^{\circ} \mathrm{C}$ for 24 hours and then weighed.

\section{Statistical Analysis}

We tested for a difference in plant density between seeded and unseeded treatments for 1988 with completely randomized 2-way analyses of variance. The factors included site (3) and treatment
(2). This model was also used for the following comparisons between treatments for 1988 and for 1989: 1) total plant cover, 2) grass cover, 3) cover of wheatgrass species, 4) cover of $B$. tectorum, 5) forb cover, 6) litter cover, 7) cover of bare ground, 8) species richness, and 9) standing crop (grams dry weight).

We analyzed the difference in total plant, grass, forb, wheatgrass species and litter cover, bare ground, and species richness between 1988 and 1989, and between May and July 1989 with repeated measures analyses of variance. The difference in species diversity between treatments was investigated using relative cover to calculate $\mathrm{H}^{\prime}$ (Shannon-Wiener information index) (Whittaker 1975) and then testing $\mathrm{H}^{\prime}$ values with a $t$ statistic (Zar 1984). Relative cover was plotted against species importance to produce dominance-diversity curves (Whittaker 1975). Simpson's dominance concentration index, coefficient of community, and percentage similarity (Whittaker 1975) were used to evaluate differences in species composition and diversity.

A 2-way multiple analysis of variance was used to examine species composition between treatments and between years by comparing cover of species that occurred in at least $80 \%$ of the samples being compared. These species included Elymus lanceolatus (Scribner \& J.G. Smith) Gould (including A. riparium Scribner \& J.G. Smith, a cultivar), wheatgrass species not identified, B. tectorum, Crepis actuminata Nutt., Lomatium triternatum (Pursh) Coult. \& Rose, Phlox longifolia Nutt., Poa bulbosa L., and Stipa comata Trin. \& Rupr. The same multiple analysis of variance model was used to analyze standing crop of all species between treatments.

\section{Results}

Furrows openers on the rangeland drill were $30 \mathrm{~cm}$ apart. Furrows covered about $40 \%$ of the soil surface, but nearly all of the soil surface was broken or covered with disturbed soil as a result of drilling.

Forb emergence in furrows in the middle plot was 1.4 seedlings $\mathrm{m}^{-1}( \pm 0.9,95 \% \mathrm{CI})$, and grass seedlings averaged 6.8 plants $\mathrm{m}^{-1}$ $( \pm 2.5,95 \% \mathrm{Cl})$. In the upper plot, mean number of forb seedlings was $4.2 \mathrm{~m}^{-1}( \pm 1.0,95 \% \mathrm{Cl})$, and grass seedlings averaged 19.6 $\mathrm{m}^{-1}( \pm 3.9,95 \% \mathrm{CI})$. Forb emergence averaged $27 \%$, and mean grass emergence was $19 \%$. These estimates may be high, especially for forbs, because it is unlikely that all seedlings counted were from drilled seeds.

Plant density was greater in the unseeded areas than in the seeded areas in 1988 ( 877 vs. 479 plants $\mathrm{m}^{-2}, P=0.01$ ). Grass species constituted $75.55 \%$ of the plants in the seeded areas, forbs contributed $24.42 \%$ of the density, and shrubs were rare, contributing $0.03 \%$ of the total. In the unseeded treatment, $88.19 \%$ of the plants were grasses, $11.74 \%$ were forbs, and $0.07 \%$ were shrubs. Bulbous bluegrass ( $P$. bulbosa), an exotic perennial bunchgrass that is naturalized in the area, constituted much of the plant density in both treatments, but was relatively more abundant in the unseeded areas.

Plant cover in unsceded areas cxcceded that in seeded areas, and cover of bare ground was greater in the seeded areas in 1988 and 1989 (Table 3). Cover of grass species was greater in the unseeded areas in 1988, but was similar between treatments in 1989 (Table 3). Cover of wheatgrasses was similar in seeded and unseeded areas in 1988 and 1989 (Table 3), and wheatgrass cover increased in both treatments in 1989 (Table 4). Cheatgrass cover 
Table 3. Meen cover for seeded and unseeded areas inJuly 1988 and 1989 and results of 2-way analyses of variance. Cover of dead shrubs was $1.8 \%$ in the seeded area and $2.6 \%$ in the unseeded area, but differences were not analyzed. Factors are site (upper, middle and lower plots) and treatment (seeded and unseeded).

\begin{tabular}{|c|c|c|c|c|c|c|c|c|}
\hline \multirow[b]{2}{*}{ Variable } & \multicolumn{2}{|c|}{ Mean Cover } & \multicolumn{2}{|c|}{ Treatment } & \multicolumn{2}{|c|}{ Site } & \multicolumn{2}{|c|}{ Site*Treatment } \\
\hline & Seeded & Unseaded & $P<$ & DF & $P<$ & $\mathrm{DF}$ & $P<$ & DF \\
\hline 1489 & \multicolumn{2}{|c|}{$\ldots \ldots(\bar{c}) \ldots$} & & & & & & \\
\hline total plant & 12.8 & 18.3 & 0.002 & 1 & 0.360 & 2 & 0.522 & 2 \\
\hline linter & 3.9 & 5.6 & 0.037 & 1 & 0.001 & 2 & 0.434 & 2 \\
\hline grass & 6.0 & 8.3 & 0.025 & 1 & 0.001 & 2 & 0.122 & 2 \\
\hline wheatgrass spacies & 3.1 & 4.2 & 0.085 & 1 & 0.833 & 2 & 0.206 & 2 \\
\hline \multicolumn{9}{|l|}{1989} \\
\hline rotal plant & 36.5 & 45.7 & 0.001 & 1 & 0.412 & 2 & 0.886 & 2 \\
\hline bare ground & 53.2 & 41.9 & 0.001 & 1 & 0.013 & 2 & 0.853 & 2 \\
\hline linter & 8.7 & 10.5 & 0.050 & 1 & 0.006 & 2 & 0.064 & 2 \\
\hline grass & 19.2 & 21.9 & 0.098 & 1 & 0.001 & 2 & 0.005 & 2 \\
\hline Wheatgrass species & 7.1 & 6.1 & 0.061 & 1 & 0.039 & 2 & 0.546 & 2 \\
\hline
\end{tabular}

was similar in seeded and unseeded areas in both 1988 and 1989 (Table 3). Forb cover was greater in the unseeded areas for both years (Table 3).

Total plant cover for both treatments in 1989 was nearly 3 times that of $198 S$ (Table 4). Greater total plant cover in May 1989 was antributed to cover of forb species, because grass cover was similar over the growing season (Table 4). Shrubs contributed only $2 \%$ relative cover in 1988 , but increased to $6 \%$ in 1989.

Litter cover in unseeded areas was greater than that in seeded areas in 1988 (Table 3). The increase in litter cover from May to July 1989 (Table 4) is reflected in a concomitant loss of forb cover and a decrease in mean species richness (19 species in May, 17 species in July, $P<0.001$ ).

Thiry-seven vascular plant species occurred in both treatments in 1988, and 50 species were counted in 1989. The increased number of species was probably due to favorable growing conditions during that year. Although the mean number of species per transect was similar for both years in seeded and unseeded areas (9 vs. 10 species in 1988; 14 vs. 15 in 1989, respectively), $\mathrm{H}$ was larger (species more equitably distributed) for the unseeded areas (Table 5). Other diversity indexes also implied greater diversity in the unseeded treatment for all sampling periods (Table 5). Dominance-divcrsity curves for seeded areas were slightly steepar than those for unseeded areas in 1988 and 1989, but were less divergent in 1989 (Fig. 2). The coefficients of community for 1988 and 1989 were both greater than 0.8 (Table 5), indicating that samples between treatments were quite similar in terms of presence and absence of species (Whittaker 1975). Percentage similarity index (the degree to which the 2 samples are alike in quantitative representation of species) (Whittaker 1975) was also high for both years (Table 5 ).

Multiple analyses of variance revealed significant differences in cover of only 1 spacies ( $L$. triternatum) between treatments in May 1989 (seaded $=0.96$, unseeded $=1.81 \%, P<0.001$ ) and no differences in July 1988 or 1989 , but the differences in cover of B. tectortm ( $2.1 \%$ seeded vs. $1.3 \%$ unseeded, $P=0.058$ ) in May 1999 and $P$. longifolia ( $2.0 \%$ unseeded vs $1.4 \%$ seeded, $P=0.058$ ) in July 1989 were marginally significant. However, when species cover was compared between years in seeded and unseeded areas, cover of each of the species tested in the seeded areas was greater (wheatgrasses, $P<0.001 ; C$. acuminata, $P<0.001 ; P$. longifolia, $P=0.002 ; P$. bulbosa, $P=0.001$ ) in 1989 than in 1988. An increase in cover of the most important species in the seeded treatment from 1988 to 1989 probably reflects differential growth related to the ability of these species to take advantage of reduced plant density and a consequent increase in water availability. There were no significant changes from 1988 to 1989 in species composition in the unseeded areas, and only cover of $L$. triternatum dif-



Fig. 2. Dominance-diversity curves (Whittaker 1975) for seeded and unseeded areas in the City Creek burn area for July 1988 and 1989. Species are ranked according to relative importance values. Each symbol represents a single species, so the length of the curve depicts species richness. Relative cover is equally distributed among species (no dominance) when the slope is zero. 
Table 4. Mean cover in July 1988 and 1989, May and July 1989, and results of repeated measures analyses of variance. The grouping factor is site (upper, middle, and lower) and the repeated factors are either year $(1988,1989)$, or month (May, July 1989).

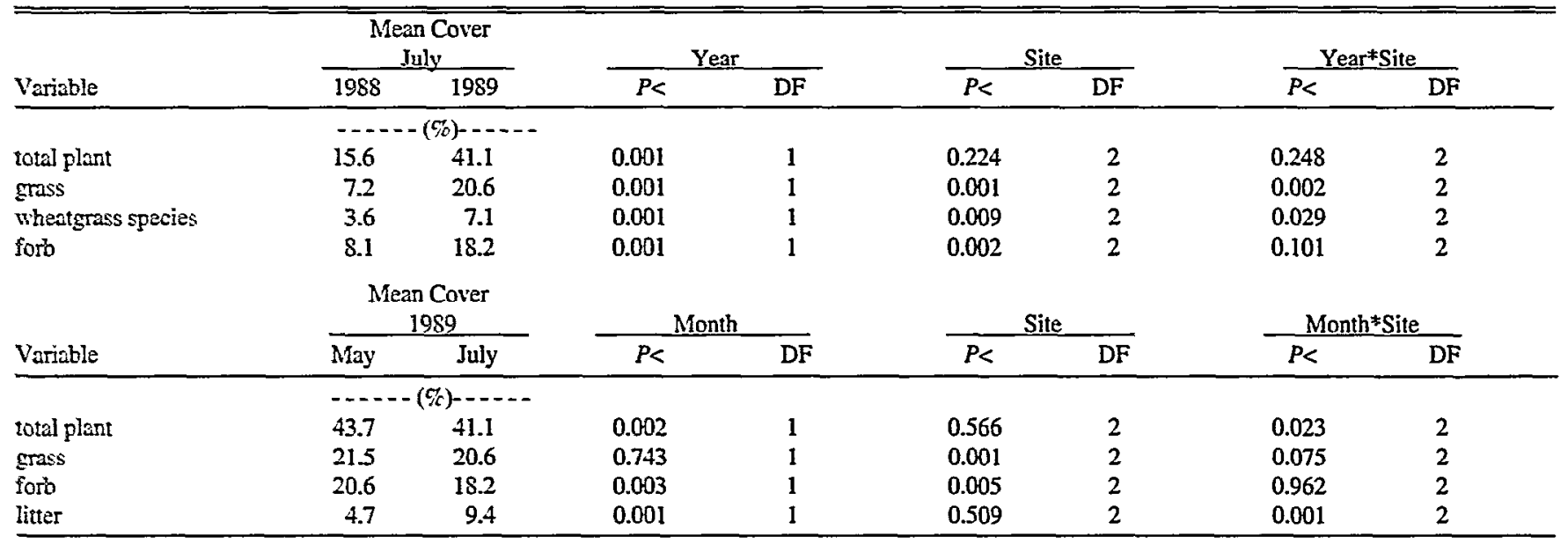

fered between May and July, $1989(P<0.001)$.

Total mean standing crop in 1989 in the seeded treatment (103 $\left.\mathrm{g} \mathrm{m}^{-2}\right)$ was similar to that in the unseeded treatment $\left(109 \mathrm{~g} \mathrm{~m}^{-2}\right)$, and standing crop of grasses, forbs, and shrubs was similar between treatments. Relative weights of growth forms in the seaded treatment were $67 \%$ grasses, $28 \%$ forbs, and $4.7 \%$ shrubs. In the unseeded treatment, relative weights were $59 \%$ grasses, $33 \%$ forbs, and $8.2 \%$ shrubs. Multiple analysis of variance showed no difference between treatments in standing crop among species. The second postfire year witnessed a nearly threefold increase in cover as a consequence of higher precipitation received during February and March. This early spring precipitation augmented soil moisture just before plants initiated spring growth (Fig. 1). Because plant density was lower in the seeded area, the similar standing crop between treatments indicates greater production per plant in the seeded areas. This is likely a consequence of the availability of more resources per individual plant.

Table 5. Diversity index values for seeded and unseeded areas in the City Creek area in July 1988, and May and July 1989. Student's $t$ was calculated for $H^{\prime}$ (Zar 1984).

\begin{tabular}{|c|c|c|c|c|c|}
\hline & $\mathrm{H}$ & $t$ & $\bar{c}$ & $\mathrm{CC}$ & PS \\
\hline Iniy 1988 & & $4.329 \div$ & & 0.85 & 0.85 \\
\hline seeded & 1.074 & & 0.127 & & \\
\hline unseeded & 1.150 & & 0.115 & & \\
\hline Misy 1989 & & $4.447 \neq \neq$ & & 0.87 & 0.88 \\
\hline seaded & 1.138 & & 0.130 & & \\
\hline unseeded & 1.194 & & 0.116 & & \\
\hline Ioly 1989 & & $6.529 \%$ & & 0.81 & 0.84 \\
\hline sezded & 1.127 & & 0.127 & & \\
\hline unseeded & 1.206 & & 0.109 & & \\
\hline
\end{tabular}

H' - Shannon-Wienar equitability index

$t$ - Student's $t$ for $\mathrm{H}^{\prime}$

c-Simpson dominance concentration index

CC-Cosficient of Commusity

PS - Percentage Similarity

*\$स P<0.001

\section{Discussion}

These findings suggest that seeding the City Creek burn was not only unnecessary, but rehabilitation efforts may have impeded postfire recovery of vegetation in this sagebrush steppe community. Drought conditions resulted in poor establishment of seeded species, hence the treatment difference between seeded and unseeded plots was due solely to the disturbance caused by drilling. Without seeding, plant cover during the first postfire season was probably adequate to stabilize soils, but cover in the seeded areas was considerably less than $20 \%$. In the following year, with average precipitation, plant cover in both seeded and unseeded areas exceeded the interagency team's estimate of prefire cover. The success of rehabilitation of burned grasslands by seeding is variable because of climatic variation, choice of species, and seeding methods (Bleak et al. 1965). We could not adequately evaluate the establishment of seeded species in the City Creek burn area the first year because the scarcity of moisture forced grasses to senesce before flowering. Therefore, we could not distinguish between seeded (exotic) wheatgrasses and native wheatgrasses Nonetheless, wheatgrass cover was similar in seeded and unseeded areas in 1988. Favorable conditions in 1989 allowed species identification of grasses; cover of seeded grasses in July 1989 comprised less than $3 \%$ of the total vegetation cover. Additionally, cover of seeded forb species was negligible in 1988 and 1989. Unquestionably, the establishment of seeded species during the first 2 postfire years was poor. Below normal snow accumulations during the winter of $1987 / 88$ provided little soil moisture recharge, and the soil surface quickly dried following meager spring precipitation. Established perennials initiated growth quickly in the spring, taking advantage of established root systems, deep water reserves, and stored carbohydrates (Flinn and Wein 1977). Seedlings were competitively disadvantaged primarily because they were smaller (Wilson 1988).

An objective of seeding the City Creek burn was to minimize the establishment of undesirable annuals, especially cheatgrass. Cover of cheatgrass in July 1988 was nominal and patchy in both seeded and unseeded areas. In 1989, cheatgrass cover increased in both treatments, but was far less than the $10 \%$ maximum goal stated in the City Creek Emergency Fire Rehabilitation Plan. It is 
interesting to note that although the variance for mean cover in the unseeded areas was larger than that in the seeded areas for all sampling periods (because cover values were much higher), the C.V. (a weighted measure of variability) was consistently larger in the seeded treatment. This implies greater relative variability in cover among samples in the seeded areas. This relationship indicates that the unseeded areas were more homogeneously vegetated, while sparsely vegetated, disturbed patches were more numerous in the seeded areas, providing favorable habitat for the establishment of cheatgrass and other annual species. Cluff et al. (1983), investigating crested wheatgrass establishment with 3 methods of sagebruch control, found significantly more cheatgrass in plowed, sprayed, and bumed areas seeded with a rangeland drill than in untreated areas.

Plant species in the sagebrush steppe of eastern Idaho evolved with a wildfire cycle of perhaps 50 years (Wright and Bailey 1982). Consequently, the life history of a species in these communities is defined by its ability to live through a fure or to establish seedlings after a fire, and by its longevity or competitive abilify after a fire (Noble and Slatyer 1980). Most of the plants that we observed in the spring following the fire sprouted from meristematic tissues that were dormant at the time of the fire. Sagebrush, easily killed by fire, appeared occasionally as seedlings in 1989. Shrub cover was a small proportion of total vegetation cover in 1988, but was 2.5 times greater in 1989. This increase following fire was similar to the findings of Humphrey (1984) and Harniss and Murray (1973). Because most species present after the fire probably occupied the site before the fire (either as plants or propagules), patterns of succession will be determined by differential rates of growth, reproduction, and survival of these species (Drury and Nisbet 1973).

Although dominance-diversity curves show a only a slight difference between treatments, the curves diverge more as species importance decreases. Therefore, fewer species constitute a sreater proportion of the cover in the seeded areas. Because the importance of seeded species was low, competition among seeded and native species is probably not a factor determining the shape of these curves. But reduction in cover and density caused by drilling may elicit other competitive relationships, reducing cover of less important (and therefore less competitive) species. Slopes are less steep and more similar in 1989, indicating a trend toward increased species equitability in both treatments. Because establishment of seeded species was poor, we can expect species composition to become more similar between seeded and unseeded areas over time.

\section{Conclusions}

The City Creek area was a diverse sagebrush/grass community of fire-adapted species at the time of the 1987 fire. Vegetative cover and plant density were reduced and the amount of bare ground was increased as a result of drilling. The seeding effort produced results counter to the objectives of the rehabilitation plan by impeding postfire recovery of vegetation on this site and probably increasing erosion potential by increasing the area of bare soil. These results emphasize the need to develop objective criteria for evaluating the necessity of postfire rehabilitation.

\section{Literature Cited}

Bleak, A.T., N.C. Frishchknecht, A.P. Plummer, and R.E. Eckert, Jr. 1965. Problems in artificial and natural revegetation of the arid shadscale vegetation zone of Utah and Nevada. J. Range Manage. 18:59-65.

CCEFRP. 1987. City Creek Emergency Fire Rehabilitation Plan. Environ. Assessment EA-ID-030-7183. USDA For. Serv., Pocatello Ranger District, Pocatello, Ida,; USDA Soil Cons. Serv., Pocatello, Ida.; USDA-BLM, Idaho Falls, Ida.

Cluff, G.J., J.A. Young, and R.A. Evans. 1983. Edaphic factors influencing the control of Wyoming big sagebrush and seedling establishment of crested wheatgrass. J. Range Manage. 36:786-792.

Drury, W.H., and I.C.T. Nisbet. 1973. Succession. J. Arnold Arboretum 54:331-368.

Flinn, M.A., and R.W. Wein. 1977. Depth of underground plant organs and theoretical survival during fire. Can. J. Bot. 55:2550-2554.

Floyd, D.A., and J.E. Anderson. 1982. A new point interception frame for estimating cover of vegetation. Vegetatio $50: 185-186$.

Harniss, R.O., and R.B. Murray. 1973. Thirty years of vegetal change following burning of sagebrush-grass rangeland. J. Range Manage. 26:322-325.

Hull, A.C., Jr. 1971. Grass mixtures for seeding sagebrush lands. J. Range Manage. 24:150-152.

Hull, A.C., and G.J. Klomp. 1966. Longevity of crested wheatgrass in the sagebrush-grass type in southern Idaho. J. Range Manage. 19:5-11.

Humphrey, L.D. 1984. Patterns and mechanisms of plant succession after fire on Artemisia-grass sites in southeastern Idaho Vegetatio 57:91-101.

Marlette, G.M., and J.E. Anderson. 1986. Seed banks and propagule dispersal in crested wheatgrass stands. J. Appl. Ecol. 23:161-175.

National Oceanic and Atmospheric Administration. 1989. Local climatological data, annual summary with comparative data, Pocatello, Idaho. National Climatic Data Center, Asheville, N.C.

Noble, I.R., and R.O. Slatyer. 1980. The use of vital attributes to predict successional changes in plant communities subject to recurrent disturbances. Vegetatio 43:5-21.

Rogler, G.A., and R.J. Lorenz. 1983. Crested wheatgrass-early history in the United States. J. Range Manage. 36:91-93.

Schuman, G.E., F. Rauzi, and D.T. Booth. 1982. Production and competition of crested wheatgrass-native grass mixtures. Agron. J. 74:23-26.

Whittaker, R.H. 1975. Communities and ecosystems. Macmillan Publishing Co., Inc. N.Y.

Wilson, J.B. 1988. The effect of initial advantage on the course of plant competition. Oikos 51:19-24.

Wright, H.A., and A.W. Bailey. 1982. Fire ecology, United States and southem Canada. John Wiley and Sons, Inc. N.Y.

Zar, J.H. 1984. Biostatistical analysis. Prentice Hall, Inc. N.J. p. 146-148. 